\title{
6 尺5寸間の発生に就いて
}

(間の建築的研究-3)

\section{前 書}

構成の主体が「flrame construction」に苟る我が国 の建築に於いて、柱間の寸法注設計基準として重要な意 味を持っている。

古来、柱間寸法を定尺に採る制があつて「文間」「8尺 間」「 7 尺間」「 6 尺 5 寸間」「 6 尺間」等はその例として あげる事が出来る。(註 1 ) 中でる「6尺 5 寸間」は俗以 「京間」之呼げれて、所謂書院造系統の建物使用され ている柱間であつて、木割書の典型と考兄られている「匠 明」に於いては、住宅建築の各部材寸法決定の基準とな つたものである。

斯様に Module としての木割の基準になつた 6 尺 5 寸 間の発生期汇於ける性格を明らかです事は、坐式居住 方式による盢という規格品を持つた我が国住宅建築の形 成過程を知る上江必要な事であると考学る。

本論はまず 6 尺 5 寸間の発生年代を規定して、従来と の発生が主として平安京の町割にあるとされていたのに 対し、住居機能の諸事情を考察して、6 尺 5 寸間発生期 の性格を検討しょうと思う。

（1）6 尺 5 寸間の発生年代 :

古代末期には完備した左右対称の所謂寝殿造はほとん ぞ見られなくなり、次第に簡略化されて来た。この傾向 を柱間寸法汇就いて考察すれ㑐、寝殿造系統の建築の柱 間は「文間」(註 2$) 、 「 8$ 尺間」(註 3$) 、 「 7$ 尺間」(註 4) 等 の如く漸次縮少の状態を示めしている事て対応しょう。

併し葠殿造の伝統は室町時代後半迄続いてはいるが、 この頃になると住宅建築は旧様式では満足出来ない要素 を带びて、新たな形式即ち書院造への変化の過程をたど つていたわけである。時応仁文明の兵火は京都の街様 を一変せしめて、鎌倉以降より曲りなりにる維持してい た平安都城の面影汇終止譜を打つたのである。丁度この 頃 6 尺 5 寸間は発生する。

私の調查した範囲では、6尺 5 寸間が記録に現われる のは、大乗院寺社雑事記、文明 13 年(1481) 1 月 25 日 の条楬矢とする。

……柇堂八本面古間南北行、奥工三間也、今度八奥工四 間分通也、面一間通八可為広縁云名、柱八山出五寸、間 八六尺五寸分也云々….....

遺構に於いて、6尺 5 寸間が見られる初期のるのとして 怯、交明17年 (1485) 建立の慈照寺東求堂の基準柱間の6尺

\footnotetext{
* 東京工業大学大学院生
}

準会員内藤昌 ${ }^{*}$

5 寸 4 分、文明末年建立と云われる山崎妙喜庵書院の 6 尺 5 寸 4 分、更汇延德元年 (1489) 建立の同じく慈照寺銀 閣（観音殿）の6尺 5 寸 3 分等があげられ、大乗院寺社 雑事記の記録と年代的飞一致している。

住宅の柱間ばかりでなく、宅地割に於いて使用された 基準単位として 1 間 6 尺 5 寸と寸る制が見られるのも この頃である。東大寺交畫、交明 18 . 年 (1486) 12 月 26日の記飞、沽却造司屋敷新券文事、合口六間の中六尺 五寸間定、奥廿一間、右此敷地者自先師相伝多年知行… ………とあり、以後東大寺文書には同様な形式で 6 尺 5 寸間の使用例をしばしば見る事が出来る。(註 5)

さて、6 尺 5 寸間の発生は文明年間をさかのぼる事は 出来ないだろろか。私の調查範囲には和のずから限界が ある為断定は出来ないが、次の如き記録がある以上、 その可能性到まずないと考光てよいと思う。即ら、図絵 類聚抄に 6 尺 5 寸間を初見した大乗院の記録関係める 後大慈三昧院殿御筆として、七郷之間、京終郷小斉間力 ス文明二年定、北ノッテ東ヨリ六間余、東ノッテ南ヨリ八 間余、西ノッテ北ョリ十二間余、辻ヨリ北ノッテ東ヨり 十二間半、过ヨリ西ノツテ北ョリ四間余、東ノッテ南ヨ り一間分、南ノッテ西ヨリ廿六間余、合六十九間六尺五 寸…(註 6) 合に六十九間六尺五寸とあつて、明らか反 ここで云う一間は六尺五寸でない事が断定出来、6尺 5 寸 間が未だ発生を見ない頃の記文と考学てよいであるう。

以上より 6 尺5 寸間の発生年代标、だいたい文明末年 (1480 年頃) と規定する事が出来るわけである。

\section{（2） 6 尺 5 寸間発生に関する従来の説 :}

6 尺 5 寸間発生の要因を探る時不思議江思うのは、何 故に 6 尺 5 寸という半端な数値を採つて規準柱間寸法に したかという事である。完数である7尺間でも6 尺間で る満足されない何等かの理由があつたと考光ざるを得な いのである。

6 尺 5 寸間々とうした特色を持つために、発生の要因 を論じた従来の諸説は主として、6.5 と云う数值を合せ る操作に終始している。それ等を整理するとだいたい 5 説あるが、代表的な 2 説を紹介したいと思う。（註 7)

A. 喜田貞吉博士の説一「歴史地理」1913.6月号所仪。 京の地割をなすにあたつて、当時の 1 里即ち 180 丈を 以て各坊の長さを定め、左右に 8 丈幅の大路と共に 4 丈 幅の小路 3 条を通じ、これを檤横に交文して坊内を16町 に分けた故、各町は 40 丈四方となる。この京内の 1 
町 40 丈を 60 分したるの即ち $6^{2} /{ }_{3}$ 尺を 1 間とした。後 に曲尺を以てこれる測るに及んで曲尺の 9 寸 7 分 5 厘は 和銅尺の 1 尺そなる事から、6 $6^{2} /{ }_{3} \times 0.975=6.5$ となりこ こに 6 尺 5 寸間が発生したという。

\section{B. 藤田元春氏の説一「尺度綜考」所収}

普通 1 町は 60 間 36 丈であるが京の 1 町は 40 丈で ある。所が式沉ると、大路広八文、自坦半至瑇辺各八 尺坦本文行、溝広各四尺、両溝間五丈六尺、小路広四文 自垣半至溝辺各五尺五寸基基三尺五寸、溝広各三尺、両 溝間二丈三尺とあつて、一つの坊ごとに周坦があり、そ の垣の半からさきは町の地面に食い込えでいる。従つて 40 丈全部を 8 間住等分する事が出来ない。そこで若干 の余裕を見て1町 40 丈を 60 間と見ないで、39丈の60 分に近い京間1間 6 尺 5 寸という長さが出来たのである。

以上 2 つ御説は数值的に厳密で明確に 6 尺 5 寸とい う長さを算出している。その限りに於いては問題はない が、建築との関係㲸て検討して見ると種々の矛盾を生ず る。以下その矛盾を検討しょう。

$A$ 説の矛盾一 6 尺 $\mathbf{5}$ 寸間が京の町割から発生したとす れイ゙、平安京の町割が完成した 8 世紀末より 6 尺 5 寸間 の存在を明らか炏するるのがあつてしかるべきである。 併し私の調查した範囲ではその傾向は全くない。6尺 5 寸間が発生するのは応仁文明の乱で平安京の面影を全く 失つた時代であるのは如何に理解したらよいであろう か。それどころか鎌倉初期に於いても、関野克博士の御 研究（註 8) に上れば、街が繁華になるにつれ間口が狭 くなって細分する傾向が生じ、間口は 25 尺程度となり 絵巻物より当時の町家怔正 3 間である所から 8 尺間前 後であつた事が云光、従つて 6 尺 5 寸間が存在したとは 一寸考光られない。又後に詳細にわたつて述べるが、建 築の柱間が 7 尺間、6尺 8 寸間、6 尺 6 寸間、そして 6 尺 5 寸間と縮少される傾向があつたのを考光合せて見ると、 6 尺 5 寸間が単飞京の町割から発生したと一元的に断定 するのは困難になつて来る。

B 説の矛盾一この説の根拠は $\mathrm{A}$ 説と同じであるから、 $\mathrm{A}$ 説で述べた矛盾はとのままここでる適応される。その 上更にこの説で問題になるのは、周垣の為に40丈を60間 と見ないで、若市の余裕䚁宁文引き 39 丈を 60 分し た事である。若千の余裕が何も1 丈でなくてはならない という理由は全くないのであるから、艺の余裕を少なく 見れば 6 尺 5 寸間でなく 6 尺 6 寸間であつてもよいわけ である。ここにもこの説の矛盾が存在するわけである。

以上、2 説を主として建築の場より検討して来たが結 局 6.5 という数值を合せる事に問題があると考党る。我 が国の度量制度が確立したのはだいたい大宝雑令の眭か らであるが、とれとしても現今の如く統一されていたわ
けでなく「法隆寺象牙尺」「㠜念尺」「攵四郎尺」「念

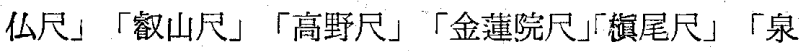
涌寺尺」「大安寺尺」…等明確飞、なつている尺度でる こんなに多くの種類があつたのだから、6 尺5 寸という 数値を合せるのに分や厘を問題にする程撖密性は要しな い。従つて、或いは 6 尺 5 寸間が京の地割に間接に関係 があつたかも知れないが、A及びB説の如く直接関係 があつたとは考光られない。

\section{（3）6 尺 5 寸間発生期の性格：}

以上の如く 6 尺 5 寸間発生飞関する従来の諸説は多く の問題を含んでいる。私は発生期に於ける性格を論じて その形成要素を探って見ようと思う。対象は主として住 宅建築に限られるが、それは 6 尺 5 寸間が初期於いて 住宅関係の建物炕多く見られるからに他ならない。

\section{A. 7 尺間}

「間」といろ言葉には様々な意味があるけれどる(註9) それが建築と結びついた最も原初的な表現は柱と柱との アイダを漠然と表現する場合である。委訓案 天の字 をよむは、あまの略なり、間は天より出たる詞にや、際 る同し、凡て家居の柱と柱との中間を云い........ そして 建物の規模を示すに何間何面と云つた形式を用いた記録 は古くから見られる所であるが、それがやがて特定の長 さ（現今我々は間と云えば 6 尺を指すと同じ意味で）を 示めす留慣を生む様になる。その初期のるのに 7 尺間を あげる事が出来る。平安遣交所収の吉井良向氏所蔵文書、 天仁 3 年 (1110) 4 月 2 日の記に、沽却家地事、合、染 尺間伍間在今小路辺、此内東方式門半、瑠璃殿渡了…… とあり、宅地割に 7 尺間が存在していた事を知るわけで ある。

その直後、門葉記、保延 6 年 (1140)10月 23 日の記飞…安 鎮九方有借屋、中方七尺間三間經九尺、八方借屋各方八 尺暴屋共 四角借屋各向角………とあつて、建物の柱間

そる7尺間を採用していた事が明らかである。として明 月記の嘉祿 2 年(1226)11月 23 日の条にも同様な記録があ つたりして、鐮倉時代初期には、1 1 間として 7 尺を採る制 があつたと考它られる。特に春日神社文書、交永 2 年 (1265) 3 月21日 前山城守重宗活券 活却家事地事 合 東西捨間南北玖間、各七尺間定…といつた記録があり、 以後東大寺交書と共飞同型式の宅地割の記録を室町中期 迄飞30余り見る所から、7 尺間 1 間制の習慣はかなり一 般化されていたと推定される。

然して、不思議にも 6 尺 5 寸間が発生する室町中期以 後には、宅地割に於ける 7 尺間の記録は泀とんぞなくな つて、唯建築の柱間だけと採用されるという傾向を見る。 もしその傾向が 7 尺間 1 間制代つて 6 尺 5 寸間 1 間制 の成立を示めするのであるとせば、6 尺5 寸間が室町中 期に発生したと先に規定した事を更に確める事になる。 
7 尺間の建築に於故る記録な、大乗院寺社雑事記、長 録 4 年(1458)、交明 18 年(1486)亿見られ、木割書の先 駆的なるのである「三代巻」に於ける基準柱間、更には 鹿苑寺金閣、奈良今西家書院の柱間も皆 7 尺間である。

「匠明」と於いては 6 尺 5 寸間と共に基準柱間とされて いるが、桃山、江戸時代化入つて、6 尺 5 寸間が一般化さ れたのに対して 7 尺間は特に格式の高い伝統的な建物、 例党ば清凉殿常御殿等との交採用されているのは注目す ベき事である。従つて、6 尺5 寸間で大成した Module の概念注 7 尺間にて初見されるわけであるが、や恼り坐 式居住方式即ち畳を利用する住宅貄築の柱間として適当 でなく、7 尺間採用の建物は濑次減少の運命をたでらな ければならなかつたのであろう。

\section{B. 9 尺8 寸間、6 尺6 寸間 :}

寝踖造系統の建物代於いては、文間、8尺間等の比較 的大きな柱間が採用されていて、小さくても 7 尺間程度 のものであつた事は、閽葉記、明月記と於ける多くの例 や、永享 4 年 (1432) 7 月 25 日室町殿御亭大㗽指図等 で知る事が出来る。そうした時に、数少ない遺構の中で 6 尺 8 寸程度の柱間を基準として設計されている建物が 多いのは全くの偶然としては見逃せないるのがある。初 期方文建築である東福寺龍吟俺、吉野朝頃の建立とされ ている（註10）吉水神社書院義経之、間、天正度の清凉 殿遺構の南禅寺大方丈（註11）にその例である。

页盢が敷き結められている部屋はすべて 6 尺 5 寸の基 準柱間を採用しているのに、畳寸法とは何等関係を持た ない広縁の部分の柱間だけは 6 尺 8 寸余の柱間を採用し ている遺構もある。文明年間建立と云われている(註12) 妙心寺小方丈はその例である。特に書写山円教寺寿量院

（註13）の場合は、畳とは無関係の広縁だけは 6 尺 8 寸 余なのに、その他の部分はすべて京間㽢 6 尺 3 寸 $\times 3$ 尺 1 寸5 分の寸法沉規制されて柱の位置が決定している。 こうした例を見ると 7 尺間と同様 6 尺 8 寸間も畳部屋飞 敷き詰めた場合、岕まり適当な寸法の柱間ではなかつた と考学られるのである。

6尺8寸間飞続いて、大乗院寺社雑事記、文明17年 (1485) の 9 月 14 日の条江………仏地院之内之丈敷事、南北行 \#三丈三十四間半六尺六寸間定…………と女つて、6 尺 6 寸間の存在を知るわけであるが、続いて同じ大乗院寺 社雑事記の文明18年(1486) 9 月11日には……成就院念所 八七尺間、泉八一文、遺水之庭東西二丈、山水南北八六丈 五尺庤縁柱マデ間影 間………記録もある。

こうして見ると、7 尺間より㳿次柱間縮少の傾向が始 まり、室町中期には 6 尺 5 寸に近い 6 尺 8 寸とか 6 尺 6 寸等の柱間寸法を採用する建物が多くなつたと考完られ るのである。

\section{C 面皘の表現としての「間」用語から「〜帖」の用 語への変化 :}

古くから、面積を表現する場合柱間一間四方を「間」 と呼ぶ習慣があつた事は、清凉殿の㫥間の例が示めして いる。そして落凉軒日録や大乗院寺社雑事記等から室町 時代には乞の習慣がかなり一般化されていたと思われ る。第 1 図は大乗院寺社雑事記所収の禅定院指図である が、それによると丁度現在の我々が一坪と云克ば一間四 方を指していると同じ意味で「間」を用いている事が明 らかである。

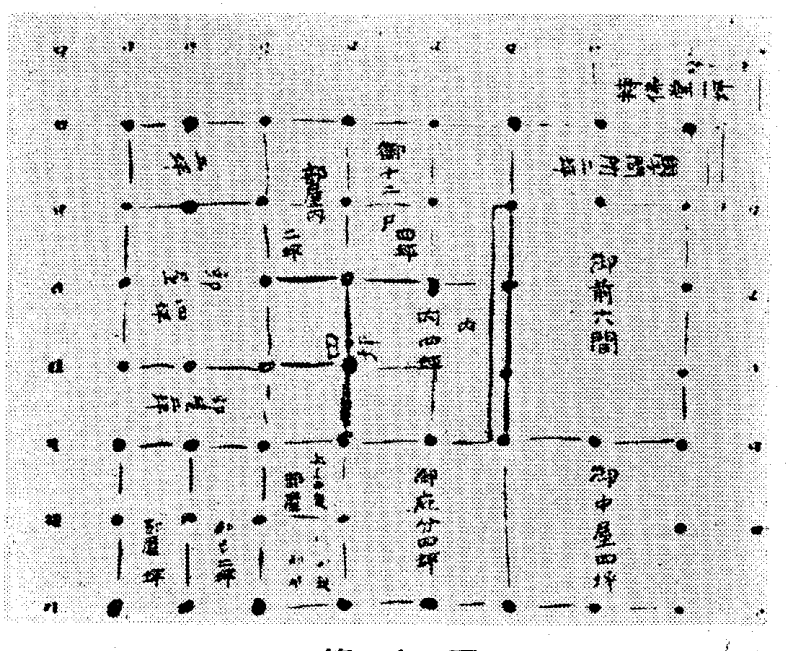

第 1 図

併し部屋の中に畳が敷き結められて来て、人々の間に 畺の意識が強くなると、柱間一間四方の「間」の用語と. 代つて、面積の共通概念として盢の枚数を云う「〜帖」 の表現が発生するのは容易江想像される。そうした意味 での記録の初期のものとして次をあげる事が出来る。

御湯殿上日記 延德 2 年(1490) 4 月 26 日………汪亏 あん寺殿御まいり しんせい上人るちようるん申、御か くもん所の三てうじきにあり……....

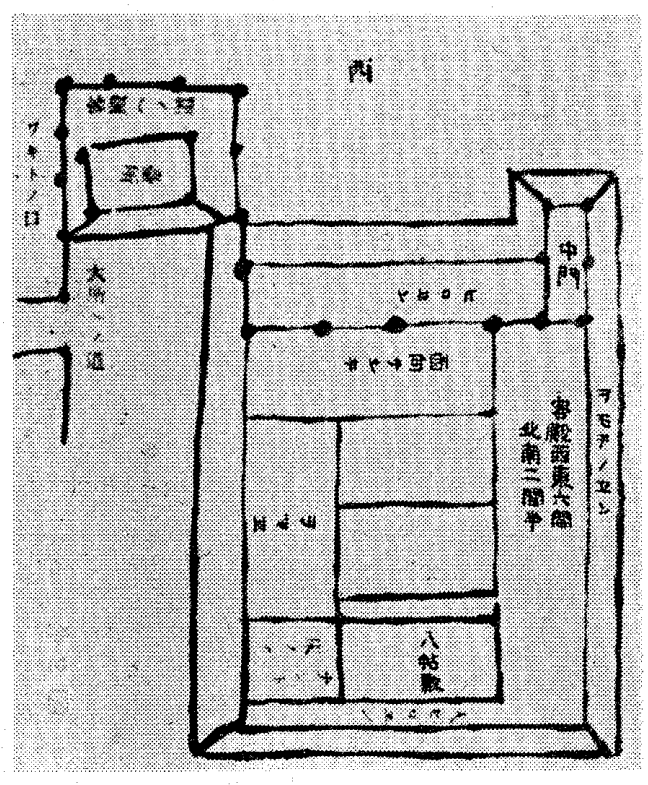

第 2 図 
以後御湯殿上日記にはこの種の用語がしばしばあり、 その他多聞院日記に应天交年間頃から同様の例を見出す る。その典型的なるのとして第 2 図の客殿の図がある。 「〜帖数」の用語が瞕を部屋化敷き詰める傾向の一般化 した時代に発生したならば、7 尺間より柱間縮少の状態 にあつて 6 尺 5 寸間が出現した文明年間直後の延徳年間

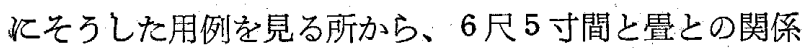
は非常に深かつたと考えてよいであろう。

\section{D.内法高}

内法高は人間の身長より必然的に決定されるべき性質 のものであろう。それは下表の如く室町時代以前の建立 と考古られている建物の内法高の実測結果を見れば明ら かである。柱間に 7 尺間、6 尺 8 寸間、6 尺 5 寸間等種 々あるのに、注とんどが 6 尺 2 寸乃至は 3 寸程度の寸法 を採つている。木割書「匠明」に於いては、古法として 内法高を6尺3寸にして和り、木割の体系の中にあつて 絶対寸法となつている。従つて室町時代に於いては、内 法高を 6 尺 3 寸程度にする習慣がかなり一般的であつた と推察される。

\begin{tabular}{|c|c|c|}
\hline & 柱 間 寸 法 & 内法高 \\
\hline 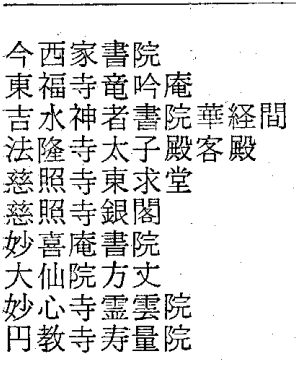 & \begin{tabular}{|l|} 
尺 \\
6.96 \\
6.83 \\
6.84 \\
6.54 を主とす \\
6.54 \\
6.53 \\
6.54 \\
6.51 \\
6.52 を主とす \\
$6.30 \times 3.15$ 疊より決定 \\
さ㣗る
\end{tabular} & $\begin{array}{l}6.32 \\
6.55 \\
6.31 \\
6.18 \\
6.29 \\
6.23 \\
6.10 \\
6.32 \\
6.02 \\
6.35\end{array}$ \\
\hline
\end{tabular}

听で、絵巻物「法然上人行状絵図」「慕帰絵」「春日 権現霊験記」等に描かれている住宅茟築を見るに、柱間 寸法と内法寸法とはほとんど同一と考えられる罒が極め て多い。

こうして見ると、室町時代に於いて内法高は6 尺5 寸 そ近似した寸法であつた事が云える。それ故、内法寸法 は人体寸法より経験的に決定されたものとせば、室町中 期に発生した 6 尺 5 寸間は、人間のスケールに適した柱 間として考えられる。

\section{（4）６尺 5 寸間の成立事情}

前節にては、6尺 5 寸間の発生期に於ける種々の性格 を論じたのであるが、とれ等から次の事が云える。

$\triangle$ 住宅建築に於ける柱間は 7 尺間から漸次縮少の傾 向にあり、室町中期には 6 尺 5 寸程度の柱間寸法（6尺 8 寸間、6 尺 6 寸間) を採る様になつた。その中でる 6 尺 5 寸間は他と異つて 2 倍すれば13尺という完数になる 数值上の利便性が比較的方る為か一般的飞使用される様 そなる。その時期として文明末年 (1480年頃)を規定する。

$\triangle$ 従つて喜田貞吉博士や藤田元春氏の御説の如く6 尺 5 寸間は京の地割より発生したと考えられる特別な事
情はないと思われる。乞れ蒢凉軒目録の長享 2 年 6 月 8 日の記に次の様にある事からす云觉る。

観音殿席其広何程可然乎之由、有御尋、愚日、凡坐具 三尺二三寸之物也、然常之六尺五寸間席、不可有子細 卓者可運席之外也云々

$\Delta$ 然して、室町中期は部屋に胃が敷き詰められると いう住宅に於ける新たな傾向の発生を見た時代である。 その傾向を示すをのとして、面積の表現の「間」の用語 そ代つて、畳の枚数を云々する「〜帖」の用語の発生を あげる事が出来る。そうした時代に形成した 6 尺 5 寸間 畳との関係が特に深い事は当然である。畳との関係の ない広縁の柱間は 6 尺 8 寸余あるのに、畳の教かれてい る部分は 6 尺 5 寸の柱間を採つている文明年間建立と云 う妙心寺小方文はそのよし例である。それ故 6 尺 5 寸間

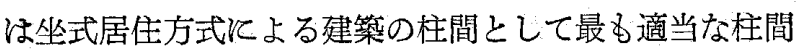
である事が考えられ、逆に云え代、畳寸法との関係に於 いて 6 尺 5 寸間が発生したとも推察される。

$\Delta$ そして、室町時代に於いて内法高柱間と近似し た值を採つて括り(註14)その内法高が人体寸法より割出 されたものであるとせば、住宅といろ人間のため方建築 の柱間として、6尺5寸間は極めてとの価值は大きいと 見なければならない。

6 尺 5 寸間の発生こそは、書院造系統の住宅建築が形 成する為の一つの前提と解すべきであろう。

\section{[註]}

（1）関東支部研、第 20 回発表会 (1956.6) 拙稿 「間の建築的研究序説」にて多くの例を示めして括 Wた。

（2）例え怔、明月記、嘉禄 2 年 11 月 13 日、新晊 上棟…中略…門内七丈館立屋狭小間、四面、其東立 持仏堂…中略…屋西有五間丈間

(3) 例えば、閽葉記、正治 2 年 9 月 12 日、大炊御門 京極御局宿所の図には 8 尺間が採用されている。

（4）例えば、永等 4 年 7 月 25 日、室町殿御亭大㗽 指図飞於いて見られる。

（5）東大寺文書：文龜元年 11 月 29 日、天文 11 月 閏 3 月

（6）とれは森總博士より御教示いたたいた。

(7) 本論で紹介する 2 説の外、新井白石の三器攻略 に於ける説、梁原信充氏の微古雑抄続篇の説、黒 川春村の碩鼠漫筆に於ける説がある。

(8) 建築史第 2 巻第 2 号「平安京の宅地割と町家」

(9) 註 1 と同じ

（10）藤原義一博士著：書院造の研究参照

（11）藤岡通大博士：南禅寺大方丈再考：美術史研究 (7) 参照

（12）重要文化財妙心寺小方丈修理工事報告書参照

(13) 野地修左博士：書写山冈教寺塔頭寿量院に就い て、研究報告第 29 号参照

（14）「匠明」では当世の方法として内法高は柱間と同 一寸法をとつている。この事はをの傾问の発展し たものである。 